\title{
Monitoring and Characterization of the Spatial Distribution of Rhynchophorus Palmarum in Conventional Oil Palm Planting
}

Artur Santos ( $\sim$ arturvfs@gmail.com )

Federal Rural University of Amazonia

\section{Paulo Farias}

Federal Rural University of Amazonia

Raphael Pinho

Federal Rural University of Amazonia

Ricardo Tinôco

Acrotech Seeds And Reforestation

\section{Brenda Silva}

Sao Paulo State University

\section{Telma Batista}

Federal Rural University of Amazonia

\section{Gisele Silva}

Federal Rural University of Amazonia

\section{Anderson Silva}

Federal Rural University of Amazonia

\section{Research Article}

Keywords: Coleoptera, Agricultural Entomology, Ecology \& Population Dynamics, GIS

Posted Date: December 21st, 2020

DOI: https://doi.org/10.21203/rs.3.rs-130179/v1

License: (c) (1) This work is licensed under a Creative Commons Attribution 4.0 International License. Read Full License 
Monitoring and characterization of the spatial distribution of Rhynchophorus palmarum in conventional oil palm planting

Artur Vinícius Ferreira dos Santos ${ }^{1 *}$, Paulo Roberto Silva Farias ${ }^{1}$, Raphael Coelho Pinho ${ }^{1}$, Ricardo Salles Tinôco ${ }^{2}$, Brenda Karina Rodrigues da Silva ${ }^{3}$, Telma Fátima Vieira Batista ${ }^{4}$, Gisele Barata da Silva ${ }^{4}$, Anderson Gonçalves da Silva ${ }^{5}$

1 Federal Rural University of the Amazon, Institute of Agrarian Sciences, Av. Tancredo Neves 2501, Brazil.

2 Acrotech Seeds And Reforestation, Rural Area, Viçosa, Brazil.

3 Paulista State University "Júlio de Mesquita Filho", Plant health Department, Acess Professor Paulo Donato Castelane Castellane, São Paulo, Brazil.

4 Federal Rural University of the Amazon, Institute of Agrarian Sciences, Av. Tancredo Neves 2501, Brazil.

5 Federal Rural University of the Amazon, Institute of Agrarian Sciences, Paragominas, Brazil

* Corresponding to arturvfs@gmail.com 


\begin{abstract}
The aim of this work was to evaluate the spatial and temporal distribution of males and females of $R$. palmarum using geostatistics as a tool. The experiment was carried out in a commercial oil palm plantation area, in the municipality of Moju (PA), Brazil. Monthly samplings were performed, from June 2013 to May 2014. The sampling of insects was carried out through bucket-type traps with pheromone and food attractant, all georeferenced. Population fluctuation, Pearson correlation and spatial analysis were performed through geostatistics. Among the abiotic factors evaluated, only relative humidity and insolation showed a significant correlation for the insect population. The spherical model was the one that presented the best fit, with ranges for males of 240 to 550 meters and females of 300 to 550 meters. The Kriging maps indicated for both sexes, a moderately pattern of aggregate infestation, located on the edges of the oil palm plantation block, mainly close to the native forest. The results indicate that the traps should be distributed on the edges of the oil palm plantations.
\end{abstract}

Keywords: Coleoptera, Agricultural Entomology, Ecology \& Population Dynamics, GIS.

\title{
1 Introduction
}

The Oil Palm (Elaeis guineensis Jacq.), or popularly known as "dendezeiro", is an african originary and in Brazil, the largest cultivared areas are found in the amazonic region¹. Brandão \& Schoneveld (2015), Studies in 2015 that the oil palm planted area identified by satellite was 250,000 hectares ${ }^{2}$. From this whole area, Pará has the largest share, accounting approximately 126,559 hectares and $86.44 \%$ of the national production of bunches of oil palm, distributed in 18 municipalities, among them, Moju, Bonito, Castanhal, Concordia do Pará, Igarapé-Açu, Moju, Santo Antônio do Tauá, Tailândia and Tomé-Açu, in which 96.44\% of the planted area and $97.04 \%$ of the state's production are concentrated ${ }^{3}$.

However, phytosanitary problems are one of the limiting factors of the exploitation of the palm oil crop, which has relevant economic expression ${ }^{4}$. Among the pests that attack this palm and cause economic losses throughout Brazil, Coleoptera Rhynchophorus palmarum L. has been highlighted as the main pest of this crop. This curculionid causes direct damage, caused by the larvae that feed on plant structures, and indirect, since they are vectors of the nematode Bursaphelenchus cocophilus (Cobb) that causes red ring disease ${ }^{5}$. For the control of $R$. palmarum an association integrated actions is carried out, in accordance with the principles of Integrated Pest Management (IPM). Among the control methods, are entomopathogenic fungi, plant traps, eradication of the plants with symptoms of this insect attack, and the most used is the bucket 
trap with food attractions associated with pheromone ${ }^{7}$, with the main purpose of monitoring the pest. The combination of sugarcane and pest aggregation pheromone increases the attractiveness of R. palmarum males and females to the traps, proving the occurrence of synergism between these attractive sources ${ }^{7}$.

However, geostatistics is an important tool to assist in any and all control methods adopted. Through this tool, it is possible to determine the spatial dependence of the pest by means of the elaboration of semivariograms, that are adjusted to a model that provides its radius of aggregation, elaborating from these, maps that show the expansion of the pest in the area ${ }^{8}$. Thus, geostatistics can be used to determine, among other parameters, the spatial distribution, the elaboration of safe sampling methods and, especially, localized insect control, such as R. palmarum in the field.

This way, the aim of the present study was to evaluate the spatial-temporal distribution of males and females of $R$. palmarum in the oil palm plantation in the municipality of Moju; evaluate the fluctuation of $R$. palmarum to show the behavior of each sex throughout the year; and evaluate the influence of abiotic factors on R. palmarum population growth.

\section{Material and Methods}

\subsection{Experimental area and population survey of insect pests}

The experimental area is located in the municipality of Moju, mesoregion of the Pará Northeast. The experiment was carried out in an oil palm plantation area belonging to the AGROPALMA group, located in the rural area of the municipalities of Tailândia, Moju, approximately $150 \mathrm{~km}$ from Belém, having access to the highway PA-150 (Fig. 1). 


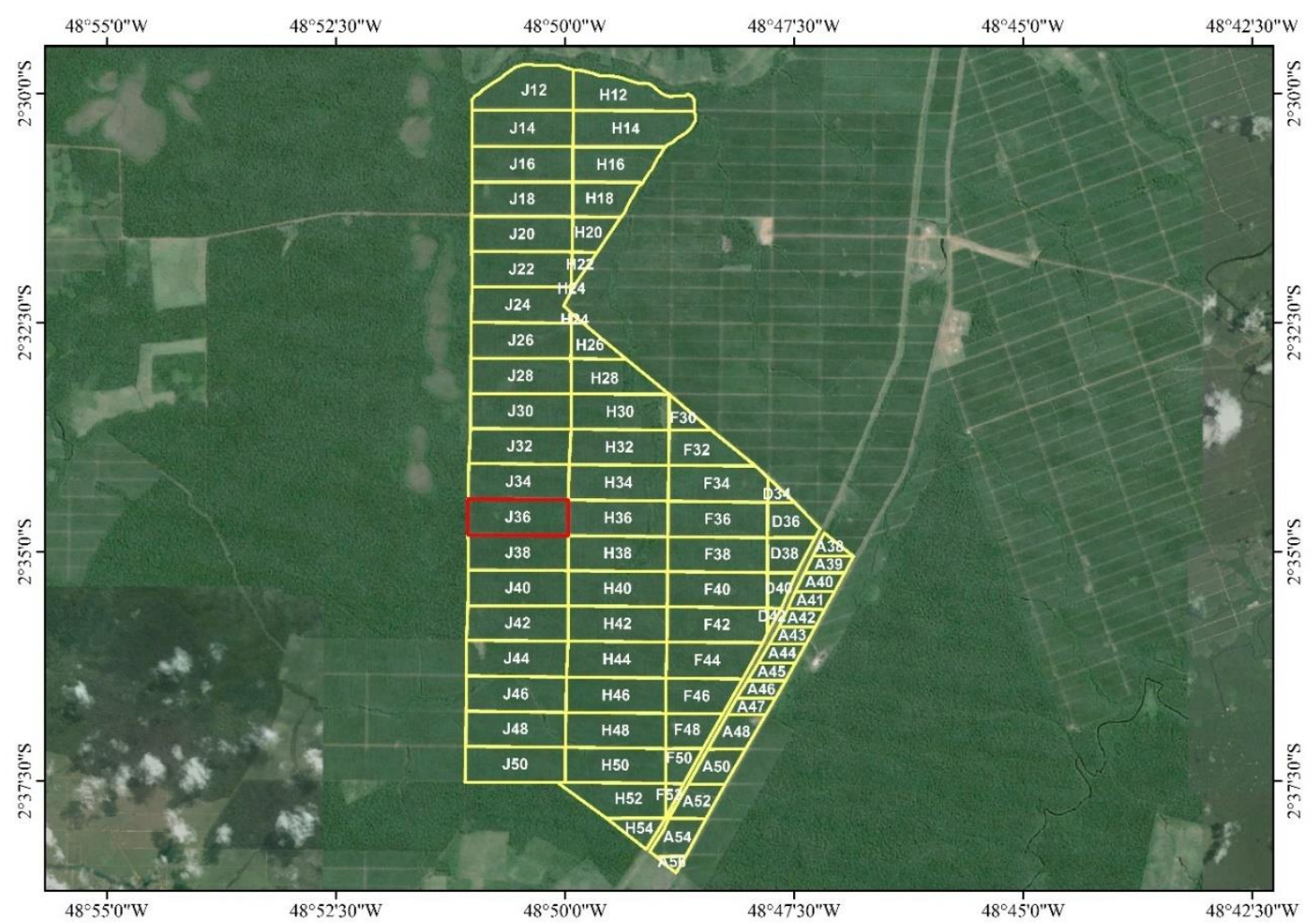

Figure 1: Location Map of Agropar Farm and experimental area $\mathrm{J} 36$ (in red) located at group AGROPALMA S. A., Acará, PA - Brazil.

The crop selected for the research is located at the Sector Agropar, block J 36, with the following geographic coordinates: Longitude: $-48^{\circ} 50$ '30,57” (West) Latitude: $-02^{\circ} 34^{\prime} 37,51^{\prime \prime}$ (South). The climate is Ami type, according to the classification of Köppen, with greater rainfall in the months of January to May and lower from August to November. The annual average temperature is approximately $26^{\circ} \mathrm{C}$ and relative air humidity of $80 \%$. Highly weathered soil with predominance of oxisol ${ }^{9}$.

The studied field, like others of this sector, has dimensions of 2,000 meters lateral and 700 meters in the vertical. A total of 147 traps were arranged in 21 lines, 18 in the oil palm block and 3 in the forest, with 7 traps per line spaced 99 meters between traps and 110 meters between lines. The experimental design was completely randomized.

The georeferencing of the blocks and traps was carried out with Geodetic GPS, Trimble brand, R6 model, which has a precision of $3 \mathrm{~mm}+0,1 \mathrm{ppm}$. Four points were tracked in the four corners of the selected court. For traps inside the court, the GPS was positioned in the direction of the trap lines to locate the lines where the trap lines are, each positioning being done in the 18 rows on the court. The GPS was positioned at a pre-set distance from the trap at the edge. With this information and spacing it was possible to have the location of each trap on the court with proper accuracy. 
The trap is composed of a bucket of $20 \mathrm{~L}$, with dimensions of $36 \mathrm{~cm}$ in height and $27.5 \mathrm{~cm}$ of medium radius. In the bucket, 20 sugar-cane tots of approximately $20 \mathrm{~cm}$ in length were added. The cover has a single hole $3 \mathrm{~cm}$ in diameter where the insects enter. This cap is hung by a copper wire, at most $10 \mathrm{~cm}$, with the porous micro plastic sachet containing Rincoforol aggregation pheromone. After 3 months another sachet is added to the wire, totaling at the end of the experiment 4 sachets per trap. The aggregation pheromone attracts and the cane keeps the insects in the bucket ${ }^{7}$.

\subsection{Obtaining climatic data and geostatistical analysis}

The average monthly climatic data such as rainfalls $(\mathrm{mm})$, average temperature $\left({ }^{\circ} \mathrm{C}\right)$, maximum temperature $\left({ }^{\circ} \mathrm{C}\right)$, minimum temperature $\left({ }^{\circ} \mathrm{C}\right)$, relative humidity $(\%)$ and solar radiation $\left(\mathrm{W} / \mathrm{m}^{2}\right)$ for that region, where the block of planted oil palm studied is located, were obtained from the meteorological station of the company AGROPALMA/AS. The correlations were determined, aiming to analyze the influence of the climatic variables on the population of $R$. palmarum, and the test of probability of Tuckey to $5 \%$.

In order to analyze the spatial distribution of the pest, the geostatistics was used, starting with the modeling of the semivariogram for each time of analysis and later the creation of the Kriging maps. The number of male and female beetles in the plot were considered the regionalized variable $\mathrm{Z}$, which can vary continuously in the geographic space. In this way, each sample was obtained the value of the variable and the Universal Tranverse Mercator-UTM coordinate of each trap collected.

Experimental semivariograms were obtained for each sample, and then the adjustments of the following mathematical models were tested: linear, spherical, exponential and Gaussian. Then, the surface maps were obtained by means of kriging, and in these are represented the pest reeds in the field.

The most important step in geostatistics is the construction of the semivariogram that informs the type and form of spatial dependence and, provides data for map construction ${ }^{10}$. It is a graph of the semivariance as a function of distance; in other words, it is a function that relates the semivariance to the distance vector, evaluating the following parameters:

The range (a) as the distance between the pairs increases, the variability will tend to increase until reaching a certain level; the distance where the variogram reaches this level is called the range ${ }^{10}$. The plateau (C), also called the sill, represents the level of variability where the variogram stabilizes. This threshold should theoretically be equal to the sample variance. Spatial Variance (C1): Represents the spatial differences between the values of a variable taken at two points separated by increasing distances. Pepita Effect $(\mathrm{C} 0)$ : 
For distance equal to zero $(h=0)$, the variogram should have zero variability. However, several factors such as sampling errors, measurement errors or even microregionalizations of the variable under analysis, cause a discontinuity in the origin of the variogram, called the nugget effect. The construction of the semivariogram is calculated by the equation:

$$
\gamma(h)=\frac{1}{2 N(h)} \sum_{i=1}^{N(h)}[Z(X i)-(X i+h)]^{2}
$$

Where $N(h)$ is the total number of pairs of beetles, separated by a distance $h$. The graph of $\gamma(h)$ versus the corresponding values of $h$, called semivariogram, is a function of distance $(h)$, being therefore dependent on the magnitude and direction of the distance (equation 1). In cases of spatially dependent variables, it is expected that the increments $[\mathrm{Z}(x i)-\mathrm{Z}(x i+h)]$ increase with the distance to a stabilization point, a threshold symbolized by $\mathrm{C}$, which approaches numerically the variance of the data ${ }^{11}$.

The semivariance increases as the distance between the samples increases, until it reaches a plateau sill, where it stabilizes. This threshold should theoretically be equal to the sample variance. The distance at which the semivariogram reaches the threshold is called the range, which corresponds to the dependence radius of the variable. The models used within this group, which presented better adjustments to the data, were:

$$
\begin{gathered}
\gamma(h)=C_{0}+C_{1}\left[\frac{3}{2}\left(\frac{h}{a}\right)-\frac{1}{2}\left(\frac{h}{a}\right)^{3}\right], \quad 0<h<a \\
\gamma(h)=C_{0}+C_{1}, \quad h \geq a
\end{gathered}
$$

The spherical model is obtained by selecting the values of the nugget effect, $\mathrm{C}_{0}$, and of the landing, $\mathrm{C}_{1}$, then passing a line that intercepts the $\mathrm{y}$-axis in $\mathrm{C}_{0}$ and is tangent to the first points close to $h=0$. This tangent will cross the plateau in the distance, $a^{\prime}=2 / 3 a$ (equation 2 ). Thus, the range, $a$, will $b e a=3 a^{\prime} / 2$. The spherical model is linear up to approximately $1 / 3 a$.

Using the parameters defined in the semivariogram adjustment $\left(\mathrm{C}_{0}\right.$ and $\left.\mathrm{C}_{1}\right)$ was calculated the portion of the variability resulting from spatial dependence or degree of spatial dependence (SDS), represented by $k$, by the relation of $\mathrm{C}_{0} /\left(\mathrm{C}_{0}+\mathrm{C}_{1}\right)$. The values obtained were classified in strong spatial dependence if $k<0,25$, moderate spatial dependence if $0,25 \leq k \leq 0,75$ and weak spatial dependence $k>0,75^{12,13,14}$.

After the parameters were taken, the kriging map was constructed from the interpolation of the points sampled to obtain an estimate, given by the following equation:

$$
Z\left(x_{0}\right)=\sum_{i=1}^{N} \lambda_{i} Z\left(x_{i}\right)
$$


Where $N$ represents the number of measured neighbors, $Z(x \mathrm{i})$, used in the estimation of property and $\lambda \mathrm{i}$ are the weights applied to each Z(xi) (equation 3), which are selected so that the estimate is not biased (Farias et al., 2002).

For the elaboration and adjustments of the semivariograms to the mathematical models, and the construction of the maps from the values estimated by kriging, the Surfer Versão 11.0 software was used ${ }^{15}$.

\section{Results}

\subsection{Temporal fluctuation of Rhynchophorus palmarum}

According to the results obtained during the samplings of adults of R. palmarum, about 19,955 beetles were collected, of which 10,142 were males and 9,813 were females. In general, the proportion of females in the population was similar to that of males (sex ratio ranging from 0.47 to 0.57 ) in all months (Fig. 2). similar studie in 2014, who observed that the female population of Sphenophorus levis Varrie, 1978 (Coleoptera: Curculionidae) similar to that of males, presented value of sexual ratio ranging from 0.44 to $0.50{ }^{16}$.

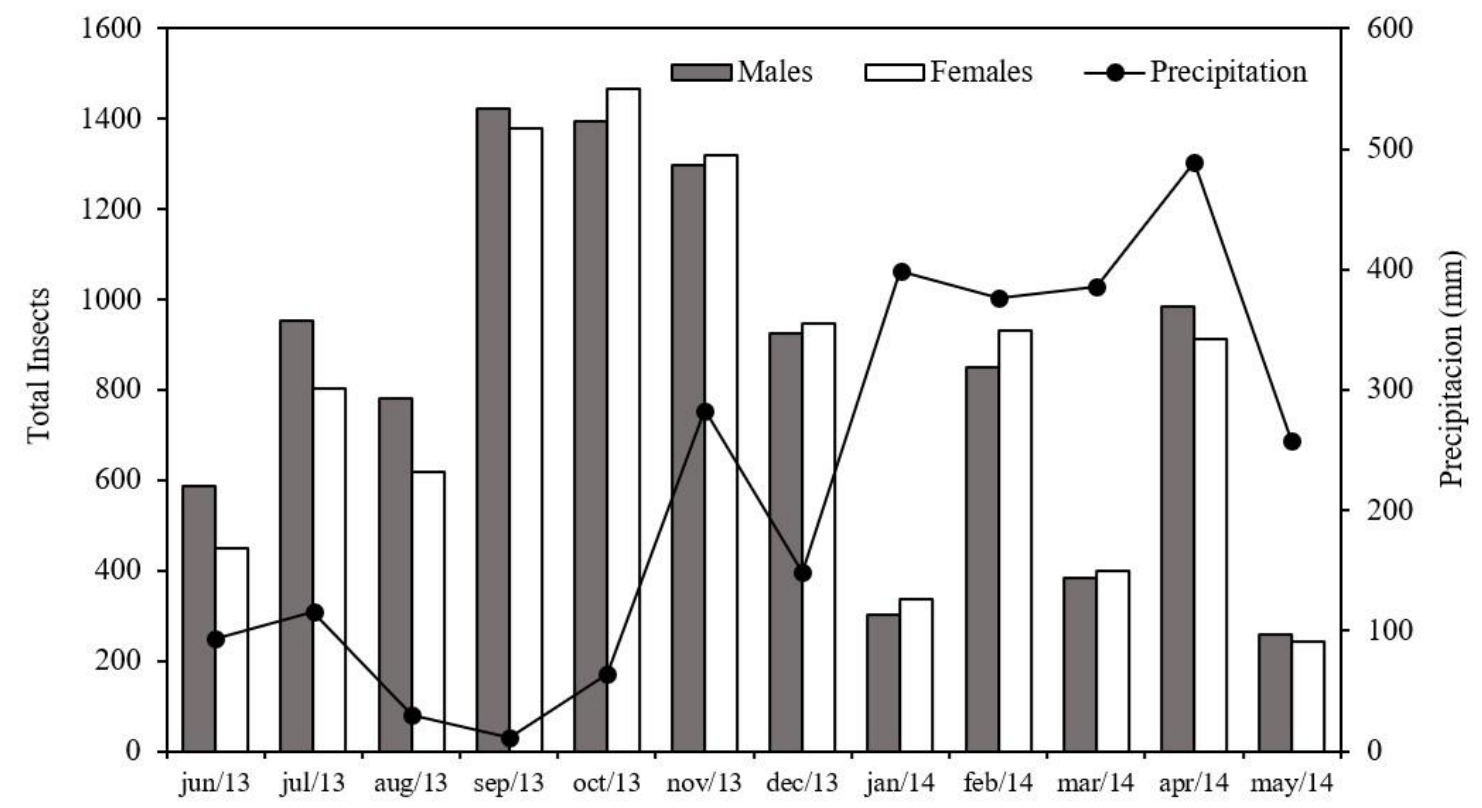

Figure 2: Relation of the population fluctuation of Rhynchophorus palmarum with rainfall ( $\mathrm{mm}$ ) in the oil palm crop from june 2013 to may 2014, Acará, PA - Brazil.

The population of $R$. palmarum varied during these 12 months of study. The pest presented its highest values in the months of September, October and November, and in January of 2014 to May of 2014 the behavior was irregular (Figure 2). A different situation occurred in an studie, who observed that in the forest environment $R$. palmarum presented its largest populations in the period from May to August and in the savanna environment in the months of July and August, in the municipality of Roraima (PA) ${ }^{17}$. 
In studie working with population fluctuation of $R$. palmarum in oil palm in the state of Amazonas verified that the amount of insects did not vary throughout the year of $2013^{6}$. For the author this may be related to the little variation of temperature and relative humidity of the air, characterized by pluviometric regularity in that region.

The period from September to November needs more attention from palm oil producers, which is the time when the population of $R$. palmarum is found to be more abundant in both sexes of the insect. After all, if there is no effective control, the palm trees may suffer a severe attack, with a population outbreak of this insect pest, as their insults can cause the transmission of the nematode causing the red ring. In the control of the red ring, the producer must eliminate the infected field plant, as well as avoid injury to the plants during the harvest, since the vector, $R$. palmarum, can transport the nematoid from a diseased plant to a healthy one ${ }^{18}$.

The influence of precipitation on the population of $R$. palmarum was shown to be inversely related. In the driest months, mainly in August and September (29.60, $11.80 \mathrm{~mm}$ respectively), in the following month the population of the beetle grew considerably presenting the largest quantities in relation to the months of study.

It was observed that the precipitation presented a negative value $\left(-0,418^{\text {ns }}\right.$ and $\left.-0,319^{\text {ns }}\right)$, indicating an inverse relationship with the beetle's males and females population, however, showed a non-significant correlation in both cases, thus statistically the precipitation is not a limiting factor in the insect population (Table 1). There was no significant correlation for the total number of males and females of $R$. palmarum with the average values of maximum, minimum and average temperature. There was a significant correlation, for solar radiation and for relative air humidity, except for insect females that did not present significant correlation for solar radiation. The relative humidity presented negative values demonstrating that these have an inverse relationship.

Table 1: Linear correlation matrix (r) for $R$. palmarum male and female adults and climatic variables, precipitation $(\mathrm{PP})$, mean temperature $(\mathrm{T})$, maximum temperature (Tmax), minimum temperature ( $\mathrm{T}$ min), Insolation (Ins) and relative humidity (RH) from june 2013 to may 2014, Acará, PA - Brazil.

\begin{tabular}{ccccccccc}
\hline & Male & Female & $\begin{array}{c}\mathrm{PP} \\
(\mathrm{mm})\end{array}$ & $\begin{array}{c}\mathrm{T} \\
\left({ }^{\circ} \mathrm{C}\right)\end{array}$ & $\begin{array}{c}\mathrm{T} \text { máx } \\
\left({ }^{\circ} \mathrm{C}\right)\end{array}$ & $\begin{array}{c}\text { T mín } \\
\left({ }^{\circ} \mathrm{C}\right)\end{array}$ & $\begin{array}{c}\text { Ins } \\
\left(\mathrm{W} / \mathrm{m}^{2}\right)\end{array}$ & $\begin{array}{c}\mathrm{RH} \\
(\%)\end{array}$ \\
\hline Male & 1.000 & $0.979^{*}$ & $-0.418^{\mathrm{ns}}$ & $0.580^{*}$ & $0.572^{\mathrm{ns}}$ & $-0.497^{\mathrm{ns}}$ & $0.620^{*}$ & $-0.698^{*}$ \\
Female & & 1.000 & $-0.319^{\mathrm{ns}}$ & $0.563^{\mathrm{ns}}$ & $0.541^{\mathrm{ns}}$ & $-0.462^{\mathrm{ns}}$ & $0.559^{\mathrm{ns}}$ & $-0.685^{*}$ \\
PP $(\mathrm{mm})$ & & & 1.000 & $-0.698^{*}$ & $-0.501^{\mathrm{ns}}$ & $0.354^{\mathrm{ns}}$ & $-0.679^{*}$ & $0.752^{*}$ \\
T $\left({ }^{\circ} \mathrm{C}\right)$ & & & & 1.000 & $0.737^{*}$ & $-0.215^{\mathrm{ns}}$ & $0.781^{*}$ & $-0.920^{*}$ \\
T máx $\left({ }^{\circ} \mathrm{C}\right)$ & & & & & 1.000 & $-0.094^{\mathrm{ns}}$ & $0.449^{\mathrm{ns}}$ & $-0.717^{*}$
\end{tabular}




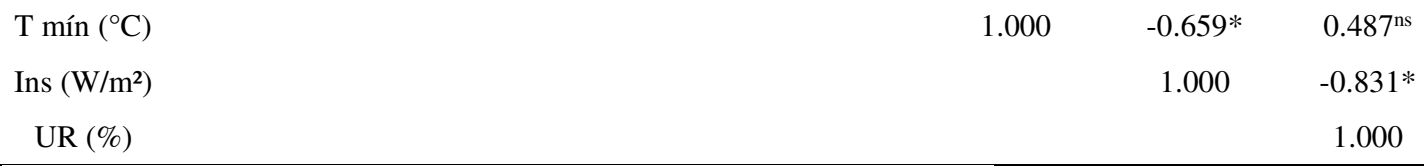

$\overline{{ }^{\mathrm{ns}}}$ not significant $(P>=0,05) ;$ *significant at the $5 \%$ probability level $(0,05=<P)$

In studie evaluating variables associated to the population fluctuation of $R$. palmarum associated to the area of influence of palm and caiaué, from the results of multiple regression, did not observe significant linear correlation between the climatic variables and the capture of $R$. palmarum in the two areas of influence considered ${ }^{19}$.

\subsection{Spatial distribution of adults of Rhynchophorus palmarum}

There was spatial dependence of the data of population density of adults of R. palmarum in both sexes. The adjusted semivariograms parameters for males and females can be seen in Table 2, respectively. The degree of spatial dependence (parameter $K$ ), given by the relation $\mathrm{C}_{0} /\left(\mathrm{C}_{0}+\mathrm{C}_{1}\right)$, of $R$. palmarum males ranged from 0.323 to 0.573 and females from 0.319 to 0.599 (Table 2). The spatial dependence of the pest was moderate for all evaluated months of adult males and females. In a study observed the spatial dependence of S. levis, which presented values varying from weak to moderate for larvae and adults ${ }^{20}$.

Table 2: Parameters of semivariograms adjusted to spherical $(\mathrm{Sph})$ model $(\mathrm{Md})$, nugget effect $\left(\mathrm{C}_{0}\right)$, sill $\left(\mathrm{C}_{1}\right)$, range in meters (a), determination coefficient $\left(\mathrm{R}^{2}\right)$ and degree of spatial dependence $(K)$, for geostatistical analysis of the population of $R$. palmarum in oil palm plantation, from june 2013 to may 2014, Acará, PA - Brazil.

\begin{tabular}{|c|c|c|c|c|c|c|c|c|c|c|c|c|}
\hline \multirow{3}{*}{ Month } & \multicolumn{6}{|c|}{ Male } & \multicolumn{6}{|c|}{ Female } \\
\hline & \multirow{2}{*}{$\mathrm{Md}$} & \multicolumn{3}{|c|}{ Parameters } & \multirow{2}{*}{$\mathrm{R}^{2}$} & \multirow{2}{*}{$K^{\mathrm{a}}$} & \multirow{2}{*}{$\mathrm{Md}$} & \multicolumn{3}{|c|}{ Parameters } & \multirow{2}{*}{$\mathrm{R}^{2}$} & \multirow{2}{*}{$K^{\mathrm{a}}$} \\
\hline & & $\mathrm{C}_{0}$ & $\mathrm{C}_{1}$ & $\mathrm{a}(\mathrm{m})$ & & & & $\mathrm{C}_{0}$ & $\mathrm{C}_{1}$ & $\mathrm{a}(\mathrm{m})$ & & \\
\hline jun/13 & Sph & 8.80 & 11.82 & 407 & 0.96 & 0.573 & Sph & 9.70 & 6.30 & 520 & 0.97 & 0.394 \\
\hline jul/13 & Sph & 22.20 & 13.20 & 400 & 0.93 & 0.373 & Sph & 13.00 & 11.00 & 350 & 0.96 & 0.458 \\
\hline aug/13 & Sph & 15.50 & 7.40 & 525 & 0.96 & 0.323 & Sph & 16.00 & 7.50 & 450 & 0.95 & 0.319 \\
\hline sep/13 & Sph & 24.55 & 16.59 & 550 & 0.98 & 0.403 & Sph & 19.50 & 20.00 & 385 & 0.98 & 0.506 \\
\hline oct/13 & Sph & 30.00 & 31.00 & 500 & 0.99 & 0.508 & Sph & 32.50 & 48.60 & 550 & 0.99 & 0.599 \\
\hline nov/13 & Sph & 25.00 & 25.00 & 500 & 0.99 & 0.500 & Sph & 33.50 & 24.50 & 540 & 0.99 & 0.422 \\
\hline $\mathrm{dec} / 13$ & Sph & 18.60 & 10.40 & 360 & 0.98 & 0.359 & Sph & 15.00 & 14.40 & 460 & 0.99 & 0.490 \\
\hline $\mathrm{jan} / 14$ & Sph & 4.70 & 2.90 & 500 & 0.97 & 0.382 & Sph & 4.40 & 3.08 & 355 & 0.98 & 0.412 \\
\hline $\mathrm{feb} / 14$ & Sph & 16.50 & 12.30 & 250 & 0.93 & 0.427 & Sph & 21.40 & 26.40 & 545 & 0.99 & 0.552 \\
\hline $\operatorname{mar} / 14$ & Sph & 5.00 & 2.66 & 336 & 0.99 & 0.347 & Sph & 5.10 & 4.85 & 520 & 0.99 & 0.487 \\
\hline apr/14 & Sph & 24.30 & 15.70 & 240 & 0.97 & 0.393 & Sph & 26.50 & 17.50 & 300 & 0.99 & 0.398 \\
\hline may/14 & Sph & 3.44 & 2.62 & 480 & 0.99 & 0.432 & Sph & 3.15 & 3.00 & 530 & 0.98 & 0.488 \\
\hline
\end{tabular}

${ }^{a}$ Relationship between $C_{0} /\left(C_{0}+C_{1}\right)$

The mathematical model that presented the best fit in all experimental semivariograms evaluated was spherical (Table 2). These models presented good values for the coefficient of determination $\left(\mathrm{R}^{2}\right)$, being that this parameter indicates the quality of the semivariogram model, values close to 1 (one) indicate good 
fit of the model ${ }^{13}$. It was observed in the present study that the coefficient showed amplitude in males from 0.93 to 0.99 and in females from 0.95 to 0.99 , indicating that the spherical models are well adjusted for the distribution of $R$. palmarum.

In study realized observed the spatial distribution of Metamasius hemipterus Linnaeus, 1758 (Coleoptera: Curculionidade), described by the spherical model, with formation of reefs ${ }^{13}$. In studies the spatial distribution of Cyrtobagous salviniae Calder \& Sands, 1985 (Coleoptera: Curculionidae) and observed that in the months when the insect population was smaller, there was a random distribution in the field, while in the months in which the largest number of insects were observed in the field, adults and larvae presented an aggregate spatial arrangement ${ }^{21}$.

Another parameter provided by semivariogram is range (a). The range value indicates the parameter's aggregate radius representing the distance at which spatial dependence occurs between the samples in the field, it must be the minimum distance considered between the sample units so that they are independent of each other and are therefore important in the detection of of this dependency (Leal et al., 2010). In the present study, the radius of the reefs found for males varied from 240 to $550 \mathrm{~m}$ and in females ranging from 300 to $550 \mathrm{~m}$, indicating that there is no difference in the spatial dependence between the sexes of this insect.

The surface maps of the population densities of $R$. palmarum, obtained by kriging, indicate that the insect population level in both sexes varied between months in the studied court (Fig. 3 and 4). These maps allow the visualization of areas with different levels of infestation, that is, the pest reeds in the field. From June 2013 onwards, it is possible to observe the beetles formed by beetle adults, both males and females (Fig. 3 and 4).

\section{Discussion}

It can be noted that the formed reefs are related to population of individuals, because in the month of June there was a greater amount of males than of females, being that the aggregation of males presented a greater amount of individuals than that of females. Observing all the studied months, these results indicate that with the passage of time, the pest insects of the field tend to differ in relation to the population of the insects in the area, and the months from September to November are more worrisome, because they presented greater quantity of the pest and is distributed throughout the block of the palm oil plantation. 
Other results obtained through the kriging map are related to the formation and location of R. palmarum formed reefs (Fig. 3 and 4). It is observed that in all months studied there was a greater presence of beetles, both males and females, located in the peripheries of the experimental area with later dissemination to the whole planting area. The highest intensity is located at the boundary between forest and the oil palm plantation block, in which it is divided by a road that serves as drainage for the harvest of bunches to the industrial processing area and smaller quantities in the center of the palm oil field.

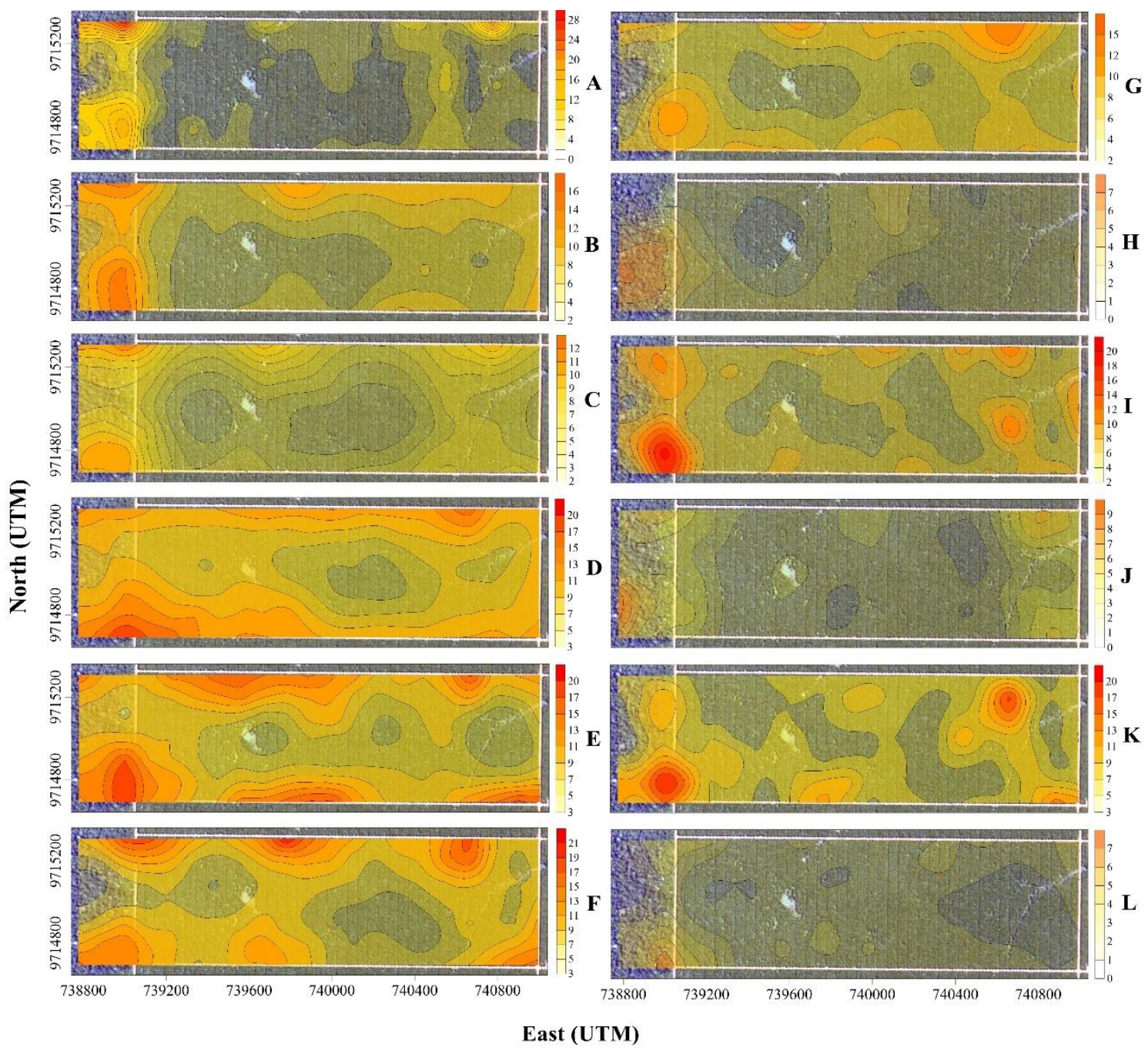

Figura 3: Kriging map of the spatial distribution of $R$. palmarum adult males in june (A), july (B), august (C), september (D), october (E), november (F) and december (G) of 2013, january (H), february (I), march (J), april (K), may (L) of 2014 at oil palm planting, Acará, PA - Brazil. 


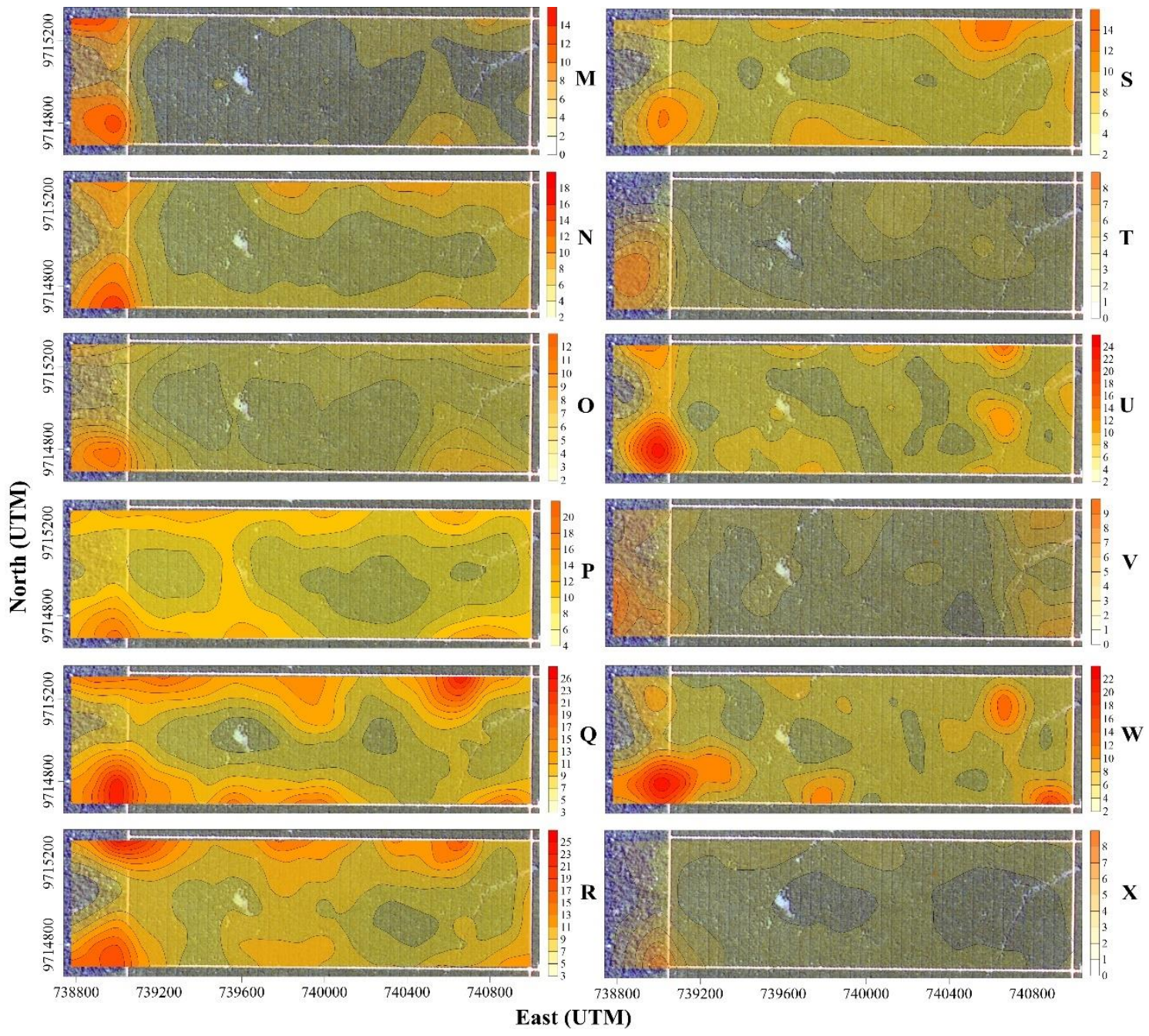

Figure 4: Kriging map of the spatial distribution of adult $R$. palmarum females in the months of june (M), july (N), august (O), september (P), october (Q), november (R) and december (S) of 2013, january (T), february (U), march (V), april (W), may (X) of 2014 at oil palm planting, Acará, PA - Brazil.

The maximum range reached is explained mainly in coleoptera, due to its ability to fly long distances, being able to reach 1,500 meters per day ${ }^{22}$. The M. hemipterus presented range values ranging from 78 to $199 \mathrm{~m}$ ${ }^{13}$. In other hand, S. levis in a sugarcane crop observed in the first cut, average reach of $21 \mathrm{~m}$, increasing to 26, 37 and $56 \mathrm{~m}$, for the second, third and fourth cuts of sugarcane ${ }^{20}$. The Diloboderus abderus Sturm 1826 (Coleoptera: Melolonthidae), found a range ranging from 125 to $195 \mathrm{~m}$, the sample size used (70 $\mathrm{m} \times 70$ m) which was adequate and enabled the correct detection of the spatial distribution of the pest, considered with strong spatial dependence ${ }^{23}$.

Other studies have been carried out with geostatistics, demonstrating that the aggregation pattern is present in several phytophagous insects. Souza et al. (2013) studied the spatial distribution of nymphs and adults of Euschistus heros Fabricius, 1798 (Heteroptera: Pentatomidae) in two areas of soybean, showed moderate 
to aggregate to random behavior in both experimental areas ${ }^{24}$. The Opsiphanes invirae Hübner, 1808 (Lepidoptera: Nymphalidae), presented its spatial distribution best described by the spherical model, forming reeds from 990 to $3,700 \mathrm{~m}$ radius in an oil palm plantation ${ }^{14}$.

As the minimum range found in the work was $240 \mathrm{~m}$, it is suggested to obtain a reliable sampling method of the pest population, and modify the distribution of the traps, being interesting to put 1 trap every $240 \mathrm{~m}$, in the palm oil, located mainly at the border ends with native forest area.

\section{Conclusion}

There was no difference between the $R$. palmarum male and female population, remaining in balance in all months studied. Precipitation has been shown to influence inversely the R. palmarum population, but is not significantly correlated. Among the abiotic factors evaluated in the present study, only relative humidity showed significant correlation for both sexes and solar radiation showed significant correlation, only in males.

Both sexes of $R$. palmarum presented a moderately aggregated spatial distribution. The spherical model presented the best fit in all experimental semivariograms, with ranges varying for males from 240 to 550 meters and for females from 300 to 550 meters.

Kriging maps indicate an aggregate pattern of $R$. palmarum infestation, located on the edges of the oil palm plantation block, mainly near the native forest. The traps should be distributed 1 every $240 \mathrm{~m}$, located in the peripheries of the blocks.

\section{REFERENCES}

1. Brazilio, M, Bistachio, NJ, Perina, VCS, Nascimento, DD. O dendezeiro (Elaeis guineensis Jacq.) Revisão. Bioenergia em Revista: Diálogos, 2: $\quad$ 27-45 http://www.fatecpiracicaba.edu.br/revista/index.php/bioenergiaemrevista/article/view/51/28

2. Brandão, F, Schoneveld, G The state of oil palm development in the Brazilian Amazon: Trends, value chain dynamics, and business models. Bogor, Indonesia, 198: http://dx.doi.org/10.17528/cifor/005861

3. IBGE-SIDRA - Instituto Brasileiro de Geografia e Estatística. Cidades: produção agrícola municipal

$$
\text { Lavoras }
$$

Temporárias

e

Permanentes.

http://www.sidra.ibge.gov.br/bda/tabela/protabl.asp?c=1613\&z=p\&o=29\&i=P> 
4. MacLeod A, Hussein M, Economic and social impacts of Rhynchophorus ferrugineus and Paysandisia archon on palms. In: Soroker V, Colazza S (eds) Handbook of major palm pests: biology and management. John Wiley \& Sons Ltd, Chichester, 54-68 (2017). https://doi.org/10.1002/9781119057468.ch3

5. Krug C, Bittencout DMC, Barcelos E, Rodrigues MRL, Angelo PCS, Rocha RNC, Cunha RNV, Quisen RC, Lopes R, Rios SA, Lima WAA Plano estratégico da Embrapa Amazônia Ocidental para a cultura

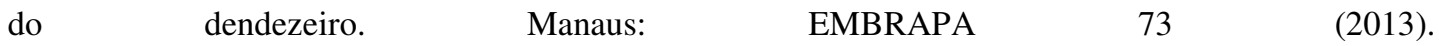
http://ainfo.cnptia.embrapa.br/digital/bitstream/item/100666/1/Doc-102.pdf

6. Cysne, AQ, Cruz, BA, Cunha, RNV, Rocha, RNC. Flutuação populacional de Rhynchophorus palmarum (L.) (Coleoptera: Curculionidae) em palmeiras oleíferas no Amazonas. Acta Amazonica, 4: 197-202 (2013). http://dx.doi.org/10.1590/S0044-59672013000200010.

7. Rodríguez C, Oehlschlager AC, Chinchilla CM Examination of critical components of Rhynchophorus palmarum pheromone traps. ASD Oil Palm Pap, 46: 15-19 (2016). http://www.asdcr.com/images/PDFs/OilPalmPapers/ASD-Oil_Palm_Papers-N46web.pdf

8. Leal RM, Barbosa JC, Costa MG, Belasque Junior J, Yamamoto PT, Dragone J Distribuição espacial de huanglongbing (greening) em citros utilizando a geoestatística. Revista Brasileira de Fruticultura, 32: 808-818 (2017). http://dx.doi.org/10.1590/S0100-29452010005000077

9. Empresa Brasileira de Pesquisa Agropecuária - EMBRAPA. Centro Nacional de Pesquisa de Solos. Sistema brasileiro de classificação de solos. 2 ed., Rio de Janeiro, 306 (2006). https://www.agrolink.com.br/downloads/sistema-brasileiro-de-classificacao-dos-solos2006.pdf

10. Vieira, SR, Hatfield, JL, Nielsen DR, Biggar, JW Geostatistical theory and application to variability of some agronomical properties. Hilgardia 51: 1-75 (1983). http://dx.doi.org/10.3733/hilg.v51n03p075

11. Farias, PRS., Sánchez-Vila, X, Barbosa, JC, Vieira, SR, Ferraz, LCCB, Solís-Delfin, J Using geostatistical analysis to evaluate the presence of Rotylenchulus reniformis in cotton crops in Brazil: Economic implications, Journal of Nematology. 34: 232-238 (2002). https://www.ncbi.nlm.nih.gov/pubmed/19265938

12. Cambardella, CA, Moorman, TB, Novak, JM, Parkin, TB, Karlen, DL, Turco, RF, Konopka, AE. Fieldscale variability of soil properties in Central Iowa soils. Soil Science Society of America Journal. 58: 1501-1511, (1994). http://dx.doi.org/10.2136/sssaj1994.03615995005800050033x 
13. Dionisio, L. F. S., Lima, A. C. S., Morais, E. G. F., Correia, R. G., Santos, A. V. F., Ximenes, C. K. S. Distribuição espacial de Metamasius hemipterus (Coleoptera: Curculionidae) em plantio de dendê (Elaeis guineensis Jacq) em Roraima. Agro@mbiente On-line, 9: 327-336 (2015). https://doi.org/10.18227/1982-8470ragro.v9i3.2517.

14. Brandão, ADS., Farias, PRS., Tinoco, RS., Dionisio, LFS., Silva, AG., Silva, TAF. Spatial and temporal distribution of Opsiphanes invirae (Lepidoptera: Nymphalidae) in oil palm, Pará State, Brazil. Revista Brasileira de Ciências Agrárias, 12: 464-469 (2017). http://dx.doi.org/10.5039/agraria.v12i4a5479

15. Golden Software. Surfer for windows: realese 11.0, contouring and 3D surface mapping for scientist's engineers user's guide. New York: Golden Software, 714 (2012).

16. Canassa, F. Distribuição espacial, efeito do manejo da palha pós-colheita e da aplicação de Beauveria bassiana (Balsamo) Vuillemin (Hypocreales Cordycipitaceae) na ocorrência de Sphenophorus levis Vaurie, 1978 (Coleoptera: Curculionidae) em cana-de-açúcar. São Paulo: Universidade de São Paulo (Escola Superior de Agricultura "Luiz de Queiroz"). Thesis, 98 (2014). http://dx.doi.org/10.11606/D.11.2015.tde-12032015-153838

17. Correia, RG, Lima, ACS, Cordeiro, ACC, Maciel, FCS, Martins, WBR, Dionisio, LFS Flutuação Populacional de Rhynchophorus palmarum L. (Coleoptera: Curculionidae) em Plantios de Palma de Óleo em Roraima. EntomoBrasilis, 8: 130-134 (2015). http://dx.doi.org/10.12741/ebrasilis.v8i2.490

18. Castro, J. M. C., Lima, C. R. F., Santana, M. L. M. P. Nematoide do Anel Vermelho do coqueiro e medidas de manejo. Petrolina: Embrapa Semiárido, 2p. (Instruções Técnicas, 88) (2009) http://ainfo.cnptia.embrapa.br/digital/bitstream/CPATSA-2010/42061/1/INT88.pdf

19. Cysne, A, Rios, S Variáveis associadas à flutuação populacional de Rhynchophorus palmarum (Coleoptera: Curculionidae) em área de influência de dendê e caiaué na Amazônia Central. Scientia Agraria Paranaensis. 16: 50-54 (2017). http://dx.doi.org/10.18188/1983-1471/sap.v16n1p50-54.

20. Izeppi TS Distribuição espacial e dinâmica populacional de Sphenophorus levis (Coleoptera: Curculionidae) em cana-de-açúcar. Jaboticabal: Universidade Estadual Paulista (Faculdade de Ciências Agrárias e Veterinárias). Thesis 74 (2015). http://hdl.handle.net/11449/128076

21. Grodowitz, MJ, Johnson, S, Schad, AN Efficiency of sampling to determine population size of Cyrtobagous salviniae (Coleoptera: Curculionidae). Florida Entomologist, 7: 1213-1225 (2014). https://doi.org/10.1653/024.097.0329 
22. Chinchilla, C. M. El síndrome Del anillo rojo-hoja pequeña em palma aceitera en cocotero. Revista Palmas, 13: 33-55. (1992) https://publicaciones.fedepalma.org/index.php/palmas/article/view/330

23. Dal Prá, E., Guedes, J. V. C., Cherman, M. A., Jung, A. H., Silva, S. JR P., Ribas, G. G. Uso da geoestatística para caracterização da distribuição espacial de larvas de Diloboderus abderus. Ciências Rural. 41: 1689-1694 (2011). http://dx.doi.org/10.1590/S0103-84782011001000002

24. Souza LA, Barbosa JC, Grigolli JFJ, Fraga DF, Maldonado JRW, Busoli AC Spatial distribution of Euschistus heros (F.) (Hemiptera: Pentatomidae) in soybean. Neotropical Entomology, Londrina, 42: 412-418 (2013). http://dx.doi.org/10.1007/s13744-013-0136-2 


\section{Figures}

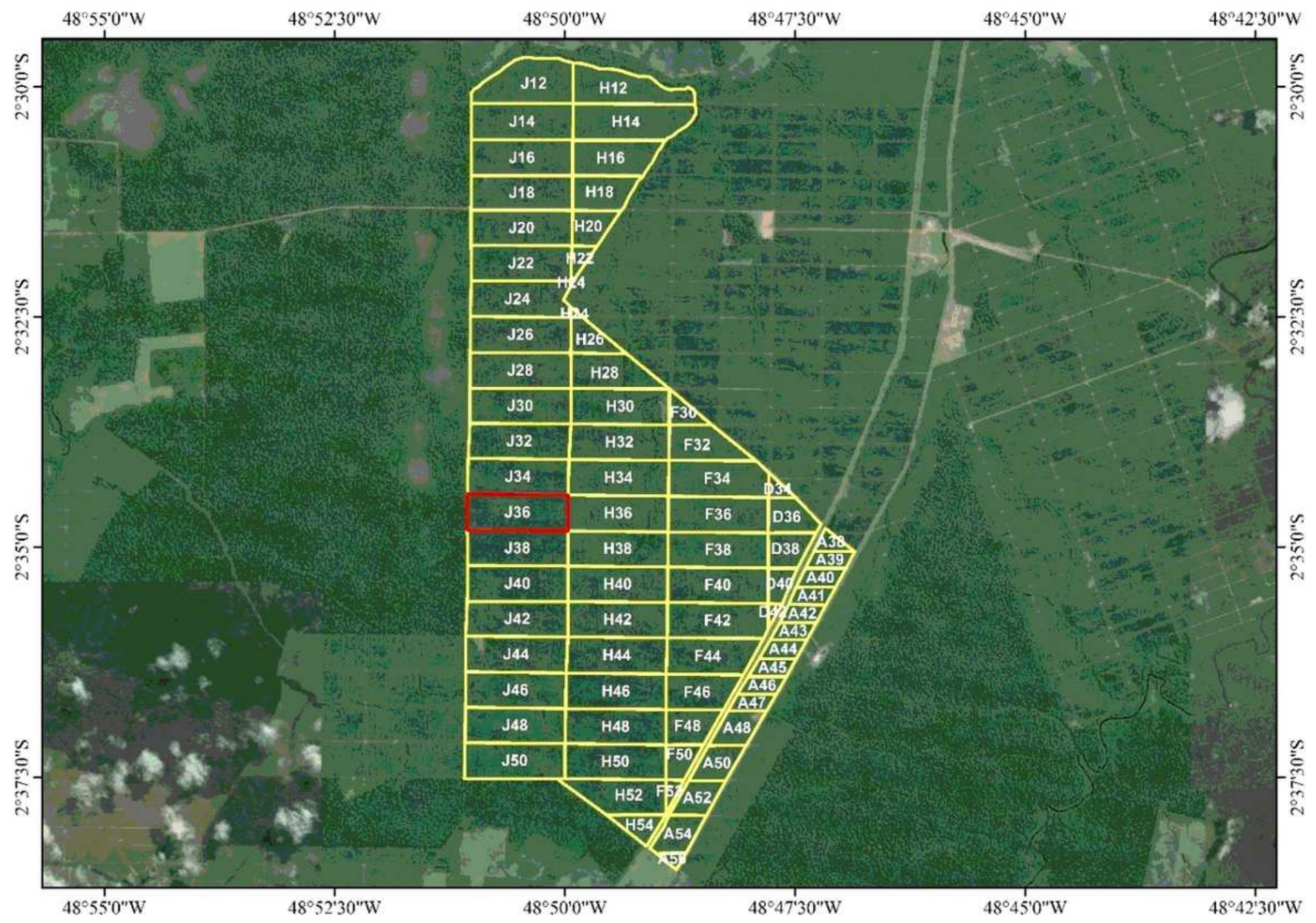

\section{Figure 1}

Location Map of Agropar Farm and experimental area J 36 (in red) located at group AGROPALMA S. A., Acará, PA - Brazil. Note: The designations employed and the presentation of the material on this map do not imply the expression of any opinion whatsoever on the part of Research Square concerning the legal status of any country, territory, city or area or of its authorities, or concerning the delimitation of its frontiers or boundaries. This map has been provided by the authors. 


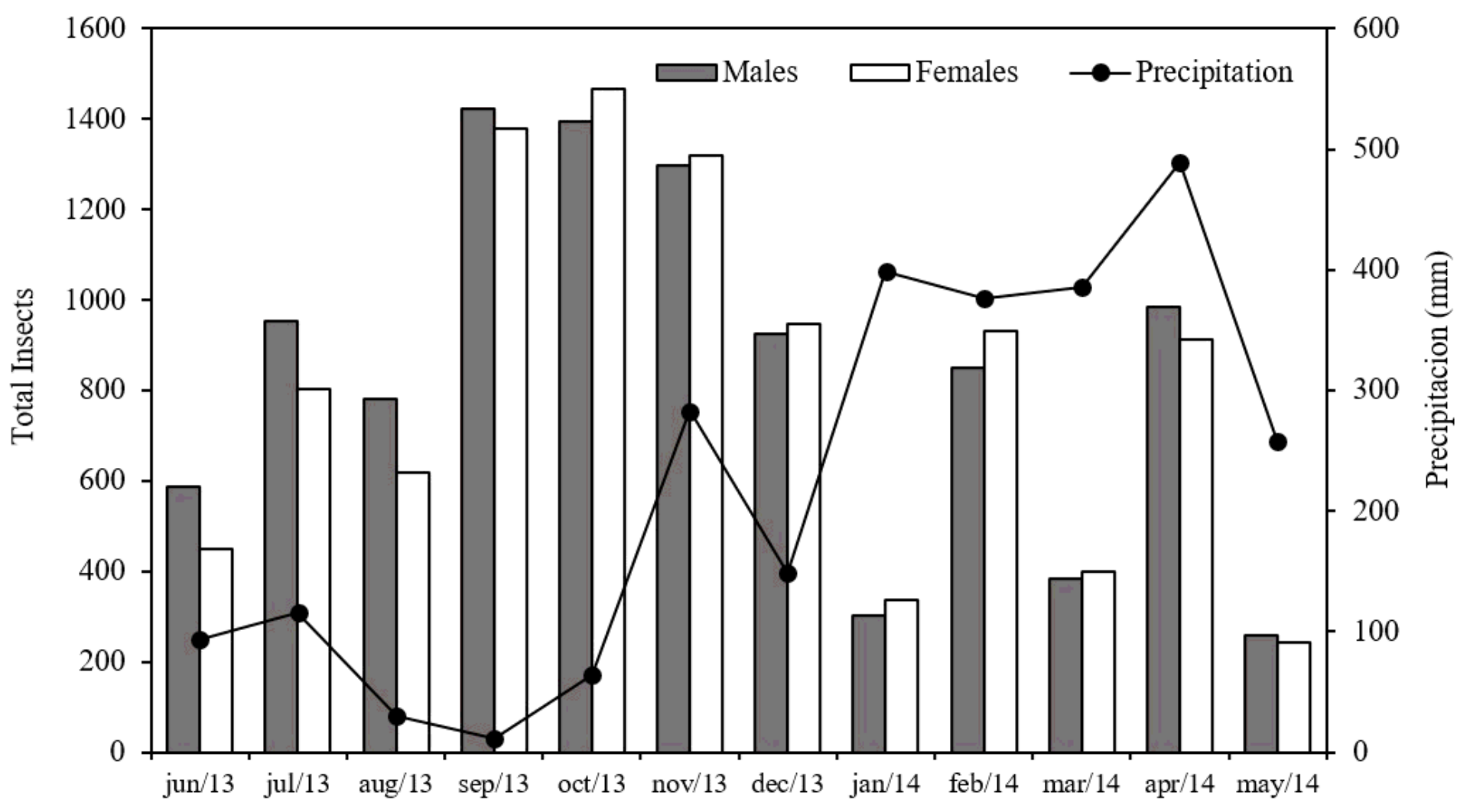

Figure 2

Relation of the population fluctuation of Rhynchophorus palmarum with rainfall $(\mathrm{mm})$ in the oil palm crop from june 2013 to may 2014, Acará, PA - Brazil. 


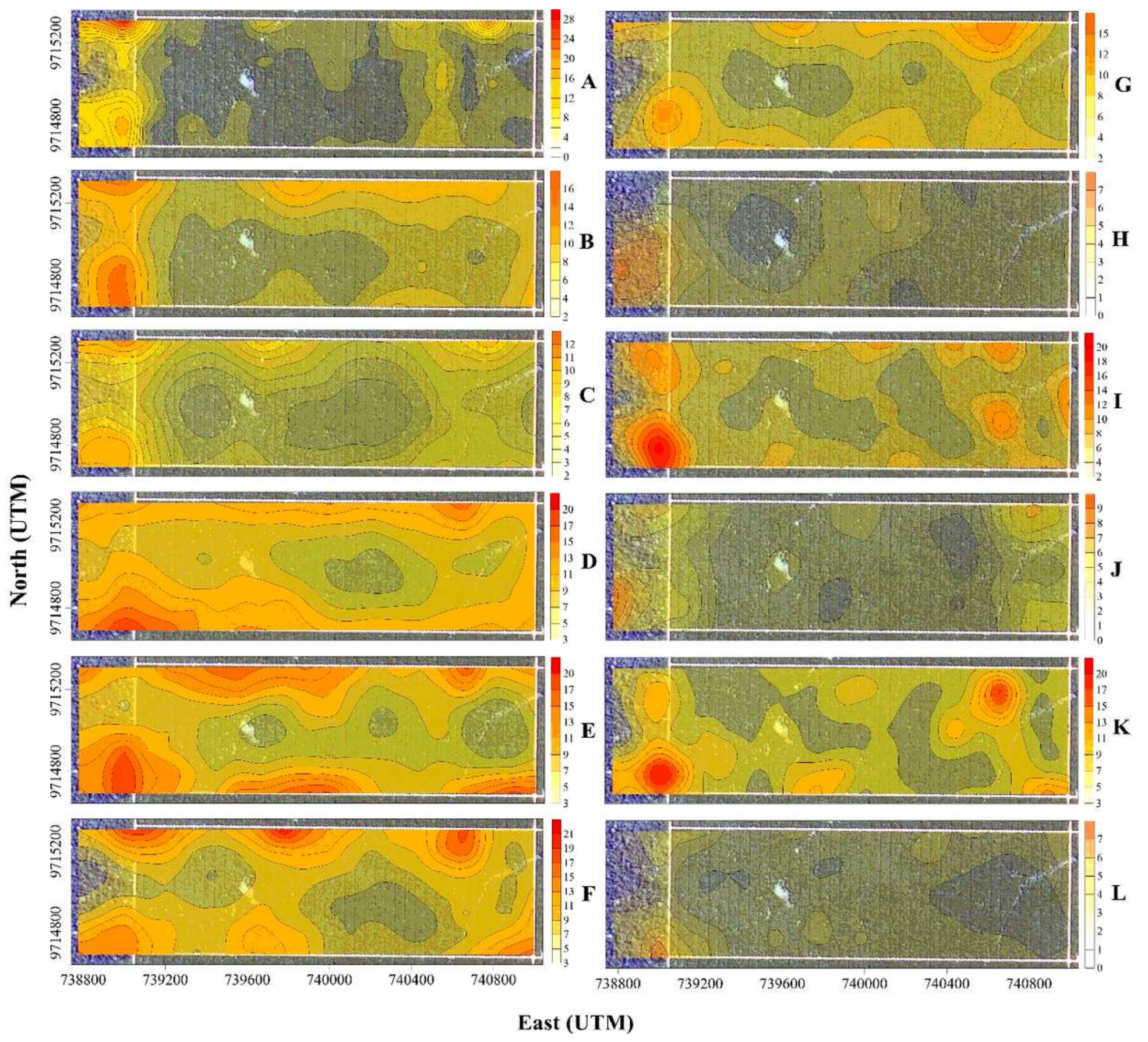

\section{Figure 3}

Kriging map of the spatial distribution of R. palmarum adult males in june (A), july (B), august (C), september (D), october $(E)$, november $(F)$ and december $(G)$ of 2013, january $(H)$, february $(I)$, march $(J)$, april (K), may (L) of 2014 at oil palm planting, Acará, PA - Brazil. 

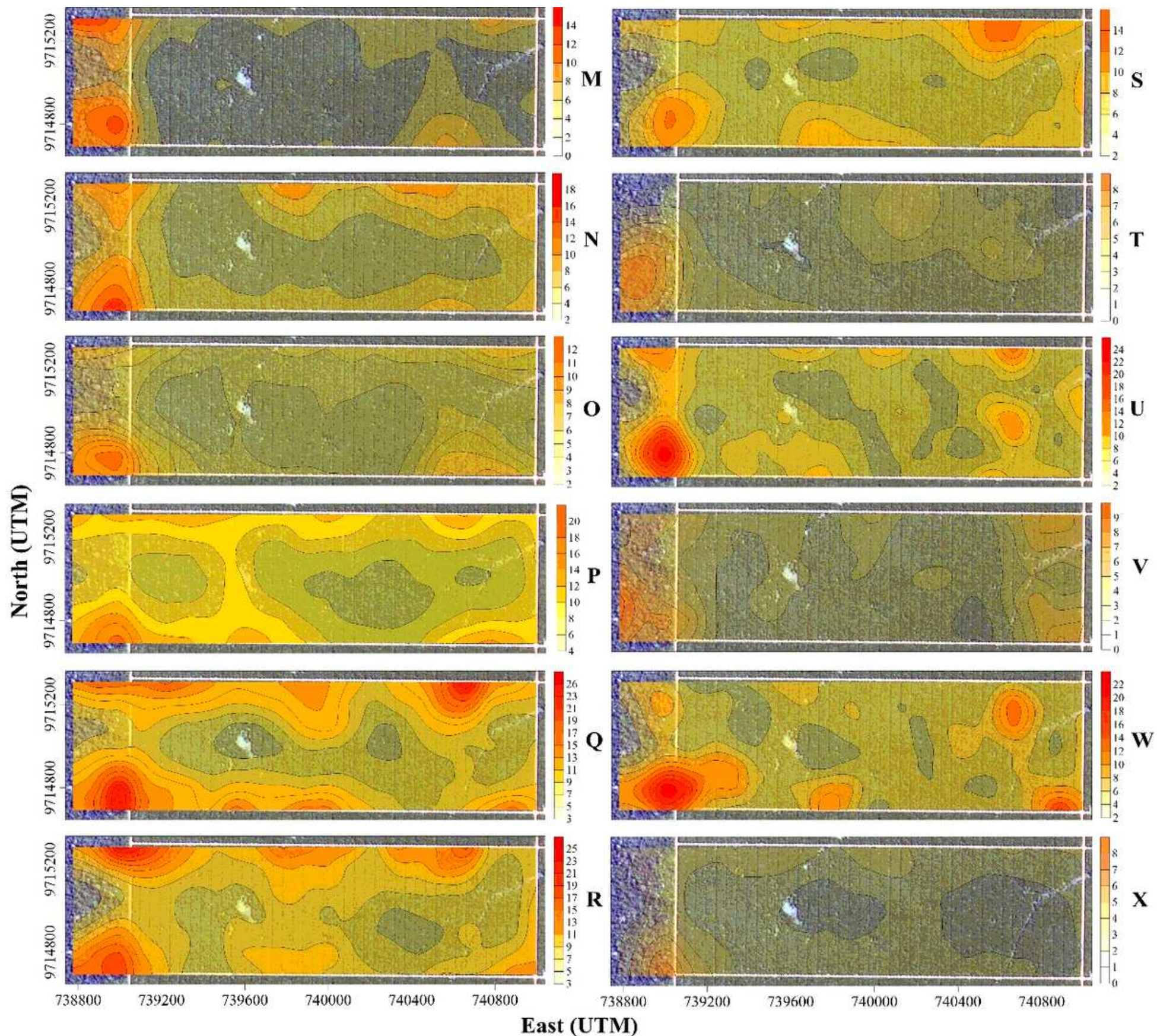

Figure 4

Kriging map of the spatial distribution of adult R. palmarum females in the months of june (M), july (N), august (O), september $(P)$, october $(Q)$, november $(R)$ and december $(S)$ of 2013 , january $(T)$, february $(U)$, march (V), april (W), may (X) of 2014 at oil palm planting, Acará, PA - Brazil. 